\title{
Not algae, not embryos, but cysts?
}

Few fossils are as hotly debated as those claimed to be of early animals - and few of those are as controversial as the tiny blobs found in the Doushantuo Formation of southern China.

The Doushantuo blobs occupy a crucial point in evolutionary history. Uncontroversially dated to about 570 million years ago, they are remains of the Ediacaran period - the time when multicellular organisms began to appear, but preceding the vast diversification of animal-body designs in the 'Cambrian explosion'.

The identity of these fossils has long been contested. Once thought to be algae, the fossils were re-interpreted in 1998 - to great palaeontological excitement - as embryos of some of the earliest animals (Nature 391, 553-558; 1998). Key to this classification was the way the organisms seemed to develop through time: a single large cell divided into two, then four, then eight cells and so on, all without growing in size. In developmental biology, this type of cell division is known as palintomy and is typical of animal embryos.

However, palintomic cell division is not unique to multicellular animals, nor have the Chinese fossils been universally accepted as animal embryos (see box).

Therese Huldtgren, of the Swedish Museum of Natural History and Stockholm University, and colleagues have now looked more closely at the Doushantuo 'embryos' and report they are not embryos, or even animals, at all (Science 334, 1696-1699; 2011).

The scientists used X-ray tomography to scan hundreds of Doushantuo fossils and generate three-dimensional images of their

\section{The journalist's take}

Palaeontologists aren't the only ones fascinated with the world's oldest animals. Journalists frequently cover studies that report an advance in understanding the early evolution of life - such as the discovery of possible 3.4-billion-year-old cellular fossils from Australia (Nature Geosci. 4, 698-702; 2011) that landed on the front page of The New York Times last August (http:// go.nature.com/SIhYgE).

The challenge for reporters is to cover the back-and-forth nature of such claims, in which one announcement is challenged by a second - and often a third or a fourth before the original hypothesis may resurface with additional evidence to support it. That story in The New York Times, for instance, traced similar microfossil arguments back to a 1993 report (Science 260, 640-646; 1993), which in turn was challenged nearly a decade later (Nature 416, 76-81; 2002) and then again in the authors' press release that accompanied publication of the latest paper. As journalists assess whether to cover a new study, they may feel a sense of déjà $v u$ - that they have already reported claim, counterclaim and yet another counterclaim.

interiors. Of the fossils studied, 14 showed internal structures that could be interpreted as cell nuclei. Then the team reconstructed how those cells developed over time using fossil 'snapshots' preserved in the rock record. Huldtgren and colleagues found no evidence that the cells started to develop differentiated

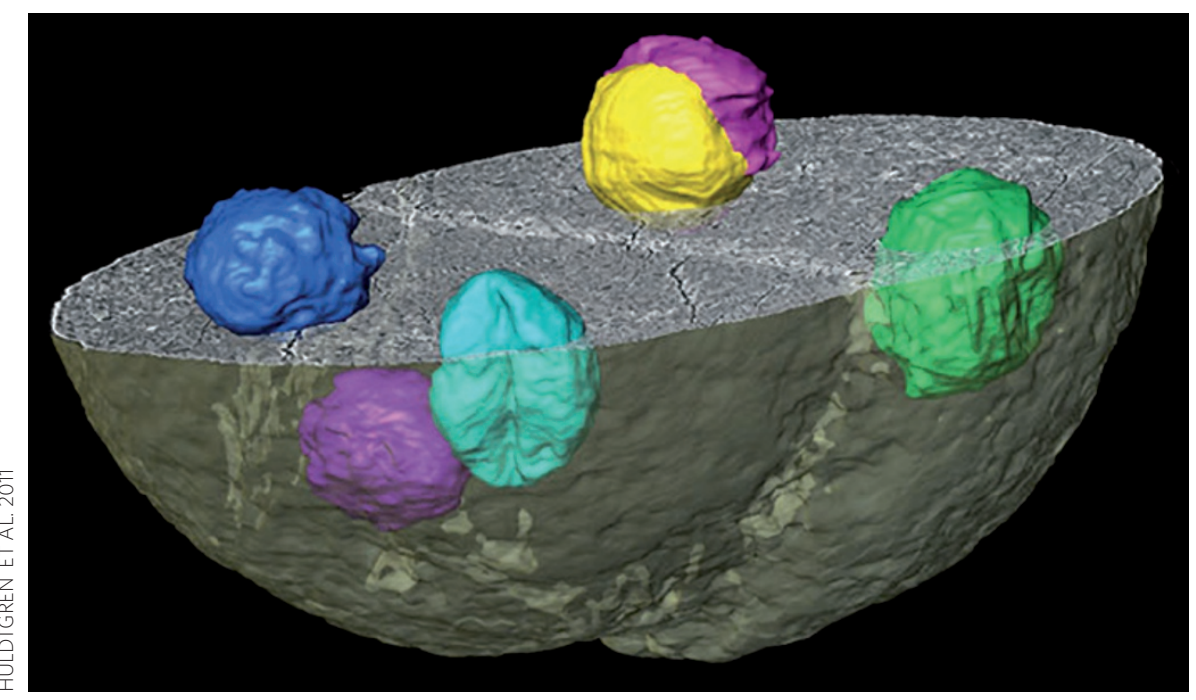
done. The nuclei-like structures also began to deform and pop out, like peanuts being extruded from their shells.

In short, the scientists say, the Doushantuo fossils cannot be animal embryos. Instead, the fossils may belong to another kind of eukaryote (the group of organisms, including animals, that have cell nuclei) known as the Mesomycetozoea. These are organisms that divide palintomically, making small spores within a cyst that bursts open and squeezes them into the environment to reproduce itself

If so, the Doushantuo fossils may turn out to be even more intriguing than anyone had thought. They may represent a new glimpse into how eukaryotes diversified early in their history.

Anyone now worried about evidence for the world's oldest animals shouldn't be. Some fossil will inevitably rise to claim that title, and is likely to be met with as much controversy as the Doushantuo organisms have.

Alexandra Witze covers the Earth and other sciences for the US biweekly magazine Science News. 